\title{
The Determination of Appendicitis from Folate Acid and Vascular Endothelial Growth Factor Level in Animal Model: A Review
}

\author{
Erjan Fikri $^{1 *}$, Putri Chairani Eyanoer ${ }^{2}$ \\ ${ }^{1}$ Department of Surgery, Division of Pediatric Surgery, Faculty of Medicine, Universitas Sumatera Utara, Medan, Indonesia; \\ ${ }^{2}$ Department of Community and Preventive Medicine, Faculty of Medicine, Universitas Sumatera Utara, Medan, Indonesia
}

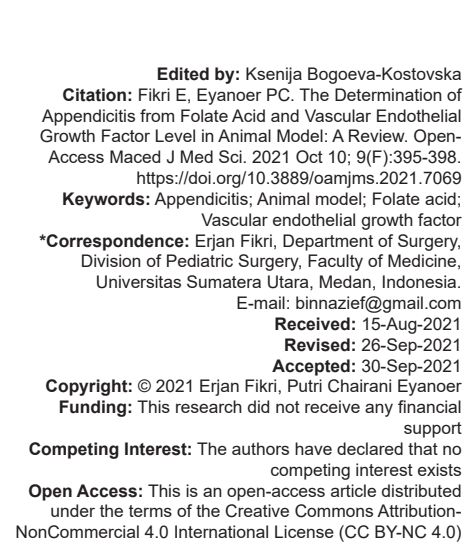

\section{Introduction}

Appendicitis is the most well-known gastrointestinal emergency requires a surgical approach in pediatric. In the $21^{\text {st }}$ century, prevalence of appendicitis fluctuated over the world, ranging from 100 in North America to 140 in Oceania. A report from South Korea stated 206 cases of appendicitis in every 100,000 population [1].

Appendicitis in pediatric has burden of the event of negative appendectomy, which surgical procedure performed on patients with normal appendix. In pediatric, the negative appendectomy rate is $8.4 \%$, however for children under 6 years, the number increases to $56.7 \%$ [2]. In a recent report in the United States, this negative appendectomy rate was $15 \%$ [3]. Hence, cost issue is an additional to problem to expend in those occasions with no appendicitis occurred [4]. Nonetheless, even with a total examination, the conclusion of an appendicitis in children did not present huge turn of events. This diagnostic challenge depends on correspondence and examination challenges [5].
Obsessively, confusions in appendicitis were related to acceptable mucosal opposition and vascularity (microvessel thickness) in the reference section mucosa. Mucosal opposition was strongly correlated to the capacity to recover, where folic acid (FA) assumes a part in this cycle [6]. Angiogenesis is additionally a significant factor tissue remodeling and healing. One factor affecting angiogenesis was vascular endothelial growth factor (VEGF), which has a pleiotropic feature in tissue remodeling through the cycle of neovascularization, reepithelization, and guide of extracellular framework [7]. This VEGF is explicit to vein endothelial cells [8].

Current development in laboratory diagnosis with biomarkers supports and increases accuracy in diagnosis of appendicitis, namely, severe appendicitis. This may suppress the rate of negative appendectomy. In contrast, there were no current guideline mentioning such approach [9]. These mechanisms were associated to activity of subepithelial macrophages and the surface epithelium in the appendix with luminal antigens which exerts a provocative reaction of inflammation in the appendix [10]. In this term, FA and VEGF may be 
identified in the appendix by histopathological approach examining microvessel thickness. Consequently, it is need for researchers to analyze the impact of FA and VEGF levels on the event of a appendicitis. Therefore, we conducted a systematic review among animal research model of VEGF and FA on account of an appendicitis.

\section{Methods}

This study was conducted in accordance with the PRISMA guidelines for reporting systematic reviews. This study reviewed experimental studies in animal model reporting the determination of appendicitis with the FA and VEGF levels that were published from 1990 to 2020 using PubMed and Science Direct. The literature search was conducted with keywords and combined by Boolean Logic of (Appendicitis OR Acute Appendicitis) AND (FA OR Folate Acid OR FA) AND (VEGF OR VEGF) AND (Animal Model). Only animal research model was included with publications ranging from 1990 to 2020. Articles instead of English were excluded due to language inability of authors. References from selected articles were inspected to detect additional potential studies. The criteria of this study were as follows: (1) Reported experimental data on the determination of appendicitis, both chronic or acute case; (2) focused on animal model; (3) they described the methods used to assess or diagnose appendicitis, FA and VEGF level; and (4) the full text was available. We excluded studies focusing on other study method (e.g. cross-sectionals, cohort, and case series) and review articles. A pre-designed data extraction form was used to extract information on the following variables: Country, sample size, appendicitis examination, FA and VEGF examination, and the result of each study.

\section{Results}

Figure 1 shows the flowchart of the literature search strategy and the study selection process. Initially, 453 potential records were identified, of which 87 were retrieved from PubMed and 366 were retrieved from Science Direct. From title screening, the articles remaining were 17 articles and eight of them were excluded for not meeting inclusion criteria in full-text read. Subsequently, data of the remaining nine articles were read and six articles were removed for not being eligible, not analyzing the determination of appendicitis with FA and VEGF levels and for not being an animal model study. Therefore, we finally included three in our systematic review.

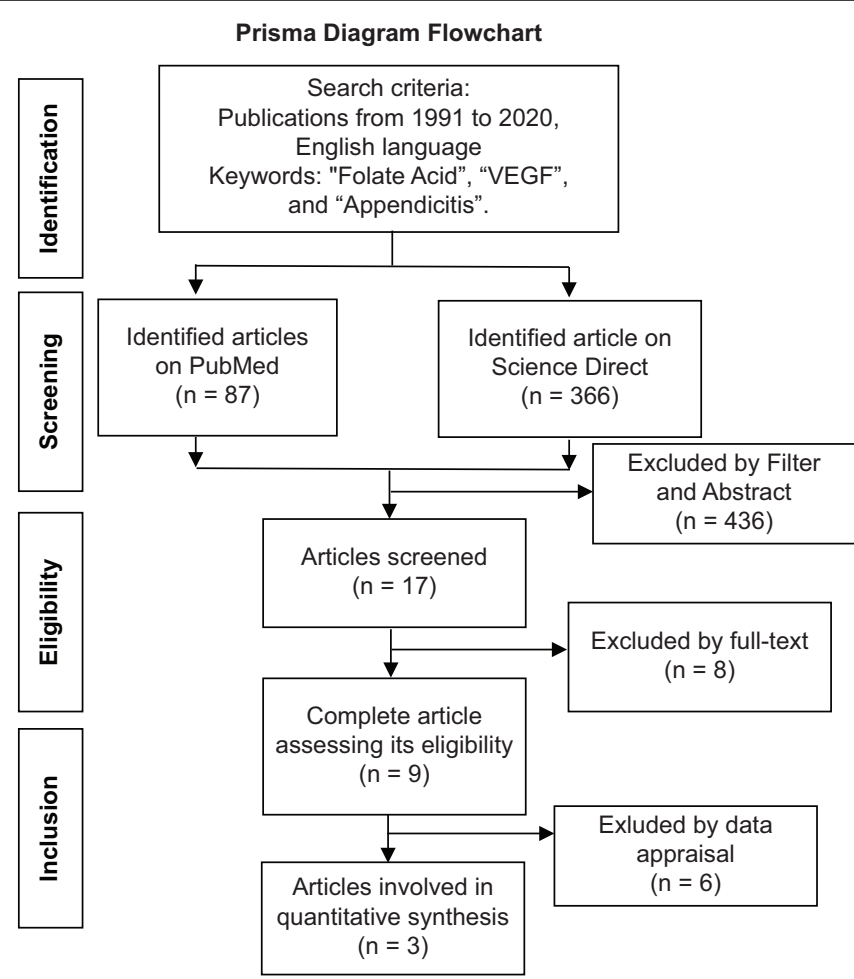

Figure 1: The PRISMA flowchart in identifying the literature included

Table 1 summarizes the characteristics of the included studies, two of which were from Indonesia and one from Israel. The sample size ranged from 20 male rabbits weighing for 2.500 to $3000 \mathrm{~g}, 32$ rabbits used were male rabbits weighing 2500 to $3000 \mathrm{~g}$, and one research used an 18 New Zealand type rabbits, males and females, 2-3 kg in weight. There three studies conducted similar methods, where obstruction of the appendix lumen with silk was no.0 at $18,24,36$, and 48 hours. Blood samples were taken for serological examination of folate acid and VEGF using ELISA method. Appendectomy was performed for histopathological examination.

\section{Discussion}

From three studies evaluated, only one study (Fenny et al., 2020) demonstrated a factually significant contrasts in the appendicitis assurance with FA. This exploration indicated that folate acid levels for all sample sources (18 h, $24 \mathrm{~h}, 36 \mathrm{~h}$, and $48 \mathrm{~h}$ ) were typically appropriated ( $p>0.05$ ), ANOVA test was directed to see distinction of folate acid levels between groups of samples. It additionally demonstrated that there was distinction in folate acid levels between groups $(p<0.05)$. Moreover, post hoc test was directed to analyze the distinction of folate acid levels in groups, utilizing least square difference indicated huge contrast of folate acid levels between samples collected in $18 \mathrm{~h}$ with $24 \mathrm{~h}, 24 \mathrm{~h}$ with $36 \mathrm{~h}$, and $48 \mathrm{~h}$. This clarifies that the connection between constant incendiary conditions, for 
Table 1: Characteristics of studies

\begin{tabular}{|c|c|c|c|c|c|}
\hline Article detail & Sample size & Methods & Treatment & Outcome & $\mathrm{p}$-value \\
\hline $\begin{array}{l}\text { Fenny, } \\
\text { et al. (2020) [11] }\end{array}$ & $\begin{array}{l}20 \text { male } \\
\text { rabbits (Oryctolagus cuniculus) } \\
\text { weighing for } 2500-3000 \mathrm{~g}\end{array}$ & $\begin{array}{l}\text { Experimental analytic } \\
\text { research on animal } \\
\text { model }\end{array}$ & $\begin{array}{l}\text { - The appendix lumen was then obstructed with silk } \\
\text { no. } 0 \text {. at } 18,24,36 \text {, and } 48 \mathrm{~h} \text {. } \\
\text { - Blood samples were taken for serological } \\
\text { examination of folate acid using ELISA method. } \\
\text { - Appendectomy was performed for histopathological } \\
\text { examination. }\end{array}$ & $\begin{array}{l}\text { Decreased levels of folate } \\
\text { acid could be a predictive } \\
\text { factor for complicated } \\
\text { appendicitis in experimental } \\
\text { animals }\end{array}$ & Folate acid $(p=0.044)$ \\
\hline Fikri, et al. (2020) [12] & $\begin{array}{l}32 \text { male rabbits (Oryctolagus } \\
\text { cuniculus) weighing } \\
2500-3000 \mathrm{~g}\end{array}$ & $\begin{array}{l}\text { Experimental analytic } \\
\text { research on animal } \\
\text { model }\end{array}$ & $\begin{array}{l}\text { - Samples were examined for VEGF levels and then } \\
\text { the appendix lumen was obstructed with silk no.-O } \\
\text { thread. } \\
\text { - Thirteen hours later, blood samples are taken back } \\
\text { to check VEGF and folate acid (FA) levels and an } \\
\text { appendectomy is performed for histopathological } \\
\text { examination }\end{array}$ & $\begin{array}{l}\text { There was a trend showing } \\
\text { low value of VEGF and } \\
\text { FA that were a predictor } \\
\text { of appendicitis and } \\
\text { complicated appendicitis. }\end{array}$ & $\begin{array}{l}\text { VEGF } \\
(p=0.755) \\
\text { Folate acid }(p=0.058)\end{array}$ \\
\hline Katz, et al. (1990) [13] & $\begin{array}{l}18 \text { New Zealand } \\
\text { type rabbits, males and } \\
\text { females, } 2-3 \mathrm{~kg} \text { in weight, } \\
\text { were used. }\end{array}$ & $\begin{array}{l}\text { Experimental analytic } \\
\text { research on animal } \\
\text { model }\end{array}$ & $\begin{array}{l}\text { - An experimental model of acute appendicitis was } \\
\text { established using no.- } 0 \text { silk ties to block the base of } \\
\text { the appendix. } \\
\text { - The clinical and histopathological picture of acute } \\
\text { appendicitis was seen after } 12 \mathrm{~h} \text { in all the rabbits } \\
\text { in the model group }(9 / 9) \text { and in none of the control } \\
\text { group. Blood samples were taken at } 0,6 \text {, and } 12 \mathrm{~h} \\
\text { for assay of LAP and Acid-P activities. }\end{array}$ & $\begin{array}{l}\text { No statistically significant } \\
\text { difference between the } \\
\text { experimental group and } \\
\text { the control group, in the } \\
\text { activities of LAP and } \\
\text { Acid-P, was found at any } \\
\text { time interval ( } p=0.928 \text { and } \\
0.802 \text { ). }\end{array}$ & $\begin{array}{l}\text { LAP }(p=0.928) \\
\text { Acid-P }(p=0.802)\end{array}$ \\
\hline
\end{tabular}

example, systemic inflammatory illness and carcinoma have a solid relationship, and perhaps including folate acid job in directing DNA solidness through DNA methylation, combination, and fix component [11].

Low folate acid serum and raised degrees of homocysteine (Hcy) were generally detailed in patients with constant provocative problems, for example, systemic inflammatory illness and rheumatoid joint pain. Folate acid has been widely concentrated in cardiovascular sickness and malignancy, with an expanded danger of this infection in those with insufficient degrees of folate acid. Folate acid is likewise a contributing element to irritation, different examinations have demonstrated connection between folate acid status with cardiovascular illness and persistent provocative infections, for example, endothelial damage. Endothelial damage was characterized as a diminishing in vasomotor tone guideline through lopsided vasodilator and vasoconstrictor levels, which makes the endothelium move toward an inflammatory state. Folate acid can forestall endothelium damage by keeping up degrees of Hcy, vasodilators, and nitric oxide [14].

Fikri et al., 2020, reported that there was a decrease in basal VEGF levels contrast to histopathological results. In appendicitis, the basal VEGF level was lower than control and typical; 8.61 $( \pm 4.87), 7.66( \pm 3.47)$, and $5.75( \pm 4.88)$, respectively. Comparative pattern was found in basal FA levels. In convoluted an appendicitis, it has a lower level than both intense an appendicitis and typical; $2.00( \pm 2.08), 1.14$ $( \pm 1.00)$, and $0.44( \pm 0.22)$ all together. However, there were no statistical significance among both groups ( $p=0.775$ and $p=0.058$ ). These outcomes have no significance but provide trend or pattern demonstrating low estimation of VEGF and FA as an indicator in diagnosis of appendicitis [12].

Other previous researches explained that plasma VEGF levels increase in a steady stage after myocardial localized necrosis and are related with incendiary cytokines, yet not with atherosclerotic weight. The study presented that expanded degrees of VEGF are important for the progressing neovascularization of aroused plaque and initiates destabilization, VEGF levels had significant negative prognostic qualities. Hypoxia-inducible factor (HIF) is a mediator that controls vascular science, angiogenesis, metabolic reinventing, and irritation [5]. HIF manages the enrollment of inflammatory cells, erythropoiesis, tissue remodeling, and $\mathrm{pH}$ homeostasis. Furthermore, metabolic variations interceded by HIF for cell maturation and replication in a hypoxic state. Effects of HIF presented by VEGF-A, required for the advancement of angiogenesis, vascular patency development in fringe blood vessel infection, stroke, and myocardial dead tissue. Secretion VEGF is restoratively helpful in restricting tissue harm because of hypoxia/ischemia [15].

In accordance with another case clarified that with the barricade of VEGF, it will make more harm the heart tissue. Thus, it tends to be inferred that the diminishing in VEGF levels will cause more serious tissue harm. In another examination, control group had higher VEGF esteems contrasted with patients experiencing chronic thromboembolic pulmonary hypertension, which represents that angiogenesis problems may occur in disease progress [6], [16].

Katz et al. (1990) stated that there were no measurably critical contrasts found between the benchmark group and the trial bunch at any of the time stretches tried of Acid-P exercises [13]. Same as LAP, no measurably huge contrasts were found between the benchmark group and the test bunch at 0,6 , and $12 \mathrm{~h}$. Between the two results no distinctive result shown in the range of 0 and 12 hours. The author clarified that their sever appendicitis causes extensive tissue necrosis and increase of permeability due to recruitment of GALT cells from circulations and vice versa. If so, one would expect changes in these particular blood test during severe acute appendicitis [17]. Author considered to quantify protein test in blood samples, before being mixed into systemic circulation with other protein expressions. This 
blood test to diagnosis may provide potency of easier identification of appendicitis [18].

There were limited reports regarding blood tests detecting biomarkers in the unanesthetized animal model. The author did not discover any of those study related to a appendicitis [19]. In this perspective, their work is likely the primary utilizing nonstop catheterization and continued inspecting of blood samples, for the estimation of chemical exercises, in a test model of severe appendicitis, which was led in 1990 [20].

\section{Conclusion}

Reduction of folate acid levels provided potency as a critical prescient factor for the severity of appendicitis in animal model, however, there was a pattern demonstrating low estimation of VEGF that was an indicator of an appendicitis and convoluted appendix with no measurable noteworthiness appeared.

\section{References}

1. Ferris M, Quan S, Kaplan BS, Molodecky N, Ball CG, ChernoffGW, et al. The global incidence of appendicitis: A systematic review of population-based studies. Ann Surg. 2017;266(2):237-41. https://doi.org/10.1097/sla.0000000000002188 PMid:28288060

2. Smink DS, Finkelstein JA, Kleinman K, Fishman SJ. The effect of hospital volume of pediatric appendectomies on the misdiagnosis of appendicitis in children. Pediatrics. 2004;113(1):18-23. https://doi.org/10.1542/peds.113.1.18 PMid:14702441

3. Turhan AN, Kapan S, KütükçüütuYiğitbaş H, Hatipoğlu S, Aygün E. Comparison of operative and non-operative management of acute appendicitis. Ulus Travma Acil Cerrahi Derg. 2009;15(5):459-62. https://doi.org/10.5505/tjtes.2013.81889 PMid:19779986

4. D'Souza N, Marsden M, Bottomley S, Nagarajah N, Scutt F, Toh S. Cost-effectiveness of routine imaging of suspected appendicitis. Ann R Coll Surg Engl. 2018;100(1):47-51. https:// doi.org/10.1308/rcsann.2017.0132

PMid:29046077

5. Rothrock SG, Skeoch G, Rush JJ, Johnson NE. Clinical features of misdiagnosed appendicitis in children. Ann Emerg Med. 1991;20(1):45-50. https://doi.org/10.1016/ s0196-0644(05)81117-5

PMid:1984727

6. Ponziani FR, Cazzato IA, Danese S, Fagiuoli S, Gionchetti P, Annicchiarico $\mathrm{BE}$, et al. Folate in gastrointestinal health and disease. Eur Rev Med Pharmacol Sci. 2012;16(1):376-85. PMid:22530356

7. Inoshima N, Nakanishi $\mathrm{Y}$, Minami T, Izumi M, Takayama $\mathrm{K}$, Yoshino I, et al. The influence of dendritic cell infiltration and vascular endothelial growth factor expression on the prognosis of non-small cell lung cancer. Clin Cancer Res. 2002;8(11):34806. https://doi.org/10.1016/s0959-8049(01)80925-4

PMid:12429638

8. Ferrara N, Henzel WJ. Pituitary follicular cells secrete a nove heparin-binding growth factor specific for vascular endothelial cells. Biochem Biophys Res Commun. 1989;161(2):851-8. https://doi.org/10.1016/0006-291x(89)92678-8

PMid:2735925

9. Marchand A, Van-Lente F, Galen RS. The assessment of laboratory tests in the diagnosis of acute appendicitis. Amer. J. Clin. Pathol. 1983;80(3):369-74. https://doi.org/10.1093/ ajcp/80.3.369

PMid:6881101

10. Giampalmo A, Berardi L, Martucciello G, Musso GL, Rossi F. Enzymatic activation of lymphoid population following inflammatory reactions in the human appendix. Mikrosk Anat Forsch. 1983;97:785.

11. Fenny N, Fikri E, Eyanoer P. Folate Acid Analysis in Predicting Complicated Appendicitis in Animal Model Oryctolagus Cuniculus. Utara: Department of Surgery, Universitas Sumatera Utara; 2020.

12. Fikri E, Lubis HM, Surya B, Siregar KB. The role of vascular endothelial growth factor as a predictor of complicated appendicitis in animal model Oryctolagus cuniculus. Open Access Maced J Med Sci. 2020;8(A):261-5. https://doi. org/10.3889/oamjms.2020.3902

13. Kats E, Hana R, Jurim O, Pisuv G, Gutman A, Durst A Experimental model of acute appendicitis in the rabbit with determination of leucine amino peptidase (LAP) and acid phosphatase (Acid-P) activities in portal blood samples. J Surg Res. 1990;48(3):230-6.

PMid:2314096

14. Brunicardi FC, Andersen DK, Billiar TR, Dunn DL, Hunter JG, Matthews JB. Schwartzs Princples of Surgery. $10^{\text {th }}$ ed. New York: McGraw-Hill Education; 2015.

15. Jones P, Lucocka M, Scarletta CJ, Veyseya V, Becketta EL. Folate and inflammation links between folate and features of inflammatory conditions. J Nutr Intermed Metab. 2019;18:1-6. https://doi.org/10.1016/j.jnim.2019.100104

16. Hansen LW, Dolgin SE. Trends in the diagnosis and management of pediatric appendicitis. Pediatr Rev. 2016;37(2):52-8. https:// doi.org/10.1542/pir.2015-0021 PMid:26834224

17. Ramakrishnan S, Anand V, Roy S. Vascular endothelial growth factor signaling in hypoxia and inflammation. J Neuroimmune Pharmacol. 2014;9(2):142-60. https://doi.org/10.1007/ s11481-014-9531-7

PMid:24610033

18. Wan J, Lata C, Santilli A, Green D, Roy S, Santilli S. Supplemental oxygen reverses hypoxia-induced smooth muscle cell proliferation by modulating HIF-alpha and VEGF levels in a rabbit arteriovenous fistula model. Ann Vasc Surg. 2014;28(3):725-36. https://doi.org/10.1016/j.avsg.2013.10.007 PMid:24345704

19. Quarck R, Wynants M, Verbeken E, Meyns B, Delcroix M Contribution of inflammation and impaired angiogenesis to the pathobiology of chronic thromboembolic pulmonary hypertension. Eur Respir J. 2015;46(2):431-43. https://doi. org/10.1183/09031936.00009914 PMid:26113681

20. Marchand A, Van-Lente F, Galen RS. The assessment of laboratory tests in the diagnosis of acute appendicitis. Am J Clin Pathol. 1983;80:369-74. https://doi.org/10.1093/ajcp/80.3.369 PMid:6881101 